\title{
WestVirginiaUniversity
}

THE RESEARCH REPOSITORY @ WVU

West Virginia Agricultural and Forestry Experiment

Davis College of Agriculture, Natural Resources

Station Bulletins

And Design

$1-1-1958$

\section{Smooth brome grass varieties for West Virginia}

O. J. Burger

Frank W. Glover, Frank W.

Follow this and additional works at: https://researchrepository.wvu.edu/ wv_agricultural_and_forestry_experiment_station_bulletins

\section{Digital Commons Citation}

Burger, O. J. and Glover, Frank W., Frank W., "Smooth brome grass varieties for West Virginia" (1958). West Virginia Agricultural and Forestry Experiment Station Bulletins. 415.

https://researchrepository.wvu.edu/wv_agricultural_and_forestry_experiment_station_bulletins/396

This Bulletin is brought to you for free and open access by the Davis College of Agriculture, Natural Resources And Design at The Research Repository @ WVU. It has been accepted for inclusion in West Virginia Agricultural and Forestry Experiment Station Bulletins by an authorized administrator of

The Research Repository@WVU. For more information, please contact ian.harmon@mail.wvu.edu. 
$1(1+1)^{1}$

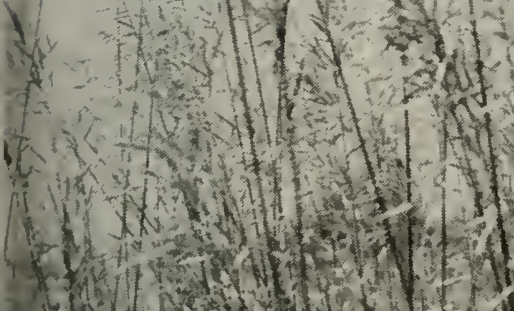

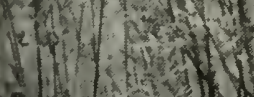

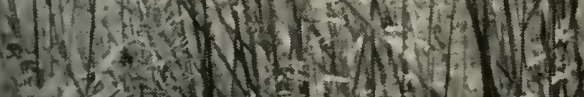

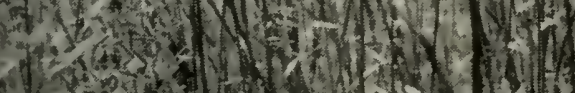

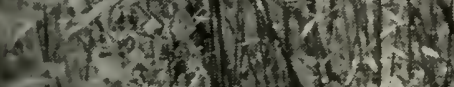
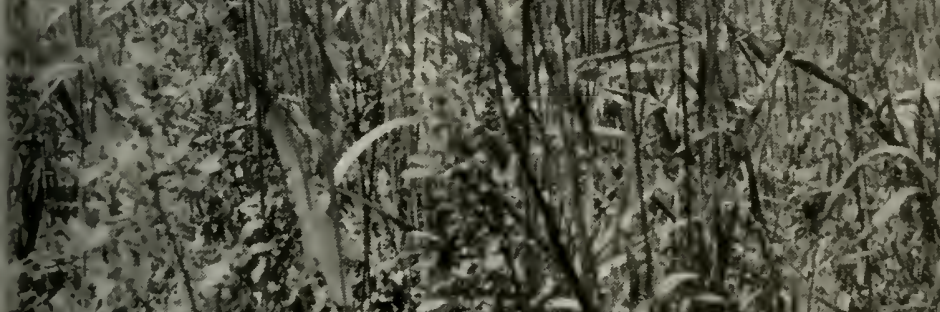

(1)

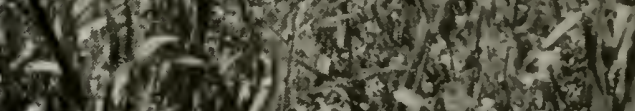

H 1 A the

\section{mooth Brome Grass Varieties FOR WEST VIRGINIA}

ulletin 415

EST VIRGINIA UNIVERSITY AGRICULTURAL EXPERIMENT STATION

June 1958 


\section{THE AUTHORS}

O. J. Burger was Agronomist at the West Virginiat Agricultural Experiment Station and Professor of Agronomy in the College of Agriculture, Forestry, and Home Economics from 1950 to 1958.

F. W. Glover, Jr. is Assistant State Soil Conservationist, United States Department of Agriculture, Soil Conservation Service, West Virginia.

\section{ACKNOWLEDGEMENT}

Acknowledgement is made to Harry $\mathbf{L}$. Porter, Jr., Plant Materials Technician, United States Department of Agriculture, Soil Conservation Service, Big Flats, New York, formerly Nanagement Agronomist, Soil Conservation Service, Morgantown, West Virginia, for cooperation in securing seed of some of the smooth brome grass varieties, in obtaining plot locations, and in assisting in laying out and seeding trial areas.

WEST VIRGINIA UNN'ERSITY

Agrigultural Experiment Station

Collige of Agriculture, Forestry, and Home Economics

A. H. Vanlandingham, Acting Director 


\section{Smooth Brome Grass Varieties for West Virginia}

\section{Introduction}

O. J. BURGER and F. W. GLOVER, Jr.

\section{A}

DAPTED grasses are needed to supply forage for the important animal industry of West Virginia. High-prodncing species are needHed to produce winter feed, since the winter feeding period for West Virginia is 150 (1) 180 days for beef cattle and sheep and even longer for dairy cattle. Smooth brome grass, Bromus inermis L., is highly palatable and is productive under a wide variety of conditions, however, it produces best on a fertile, well-drained soil.

During recent years several new strains and varietien have becul developed by breeding and selection. Improved varieties and strains (an) be recognized and craluated only by comparative testing: therelore, new releases need to be evaluated in comparison with well-known varicties. The purpose of this study was to compare vields of 11 varietice of smooth brome grass under a variety of conditions in West Virginia.

\section{Experimental}

Eleven varieties of smooth brome grass, Bromus inermis L., were secded at five locations in West Virginia in the spring and summer of 1951. The names and descriptions of varicties are given below:

Achenbach is a typical southern strain developed by some selection in the late 1890's by the Achenbath Brothers of Washington, Kansils. This early work gave the loundation toch of what is now the Achenbach train. Nost of the brome gram in castern Kansis and all of the certified brome in Kansas traces to this some. It may therefore be comidered "s be a "regional strain" dereloped under eastern Kansas conditions.

Elsbery is a southern early-ntaturing type of brome gras and in the best of several accessions tested in the Soil Comsertation service Nursery at Elsberry, Missouri. This variety of mooth brome gras is believed to be derived from an old field of hrome grass locitted neant the Missomri and Iowa border.

${ }^{1}$ The description of varletles was laken from it report promart by the lilielus af

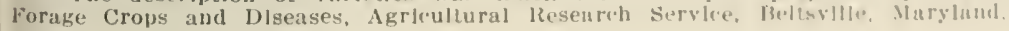




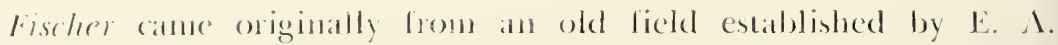
fischer in Shendncioah, Jowa in 1917. It is believed that the seed came from Ohio and it is possibly of at dillerent origin lrom many of the other brone grasses. The original collection of seed (20) pounds) wats made by the Soil Conservation Service Nursery on August 16, 1999. Tests of this stratin have been conducted by the Iowa Igricultural Experiment Station and the Soil Conservation Service from 1910 to date.

Lancaster is a relatively new strain which has been developed over a loyear perion at the Nebraska Agricultual Experiment Station, Lincoln, Nebraska. it is a synthetic variety produced by the hybridizadion of several unciated ontstanding plants. These patrental plants were selected over a period of years by meins of progeny tests and were allowed to intercross in an isolated pianting in 1942. Seed from this original hybridization wats increased and tested in several trial plantings. This vallety was known as Nebraskil 14 before it was named Lincaster.

Lincoin is a naturalized strain of biome grass of Hungarian origin. It has proved particularly well adapted to the central latitudes of the United States and constiutes an excellent source of unselected material to be used in tire production ol selected new strains for the same region. Increase and lomndation secel stocks are maintained at the Nebraska Agricultural lixperiment Station, Lincoln, Nebraska.

Lyon, formerly known as Nebraskat 96 , is a selection of the Lincoln 1) pe which is being increased for larm use. It was produced by two gencrations of selection wilhin a fanner's strain of Lincoln bronc grass lollowed i) one generation of ontcrossing of this material to a wide sonrce of carefully selected brome grass plants in a spaced plant nursery. The selection shows considerable refinement of plant charactcrs over Lincoln brome grass. It is outstanding in production of high quality, relatively heavy seed, and it retains the adaptation of Lincoln for critical planting sites.

Manchar is a tall, leafy, semi-bunch type of brome grass introduced from Manchuria. It was subjected to mass selection at Pullman, Washington. Its outstanding chatrateristics are seedling vigor and high seed production. It is intermediate in growth habit between the sonthern type ats excmplificel by Achenbach and the northern type of smooth brome grass.

Martin was obtaincel from an old brone grass field in Martin Comnty, Minnesota. Eighty-eight plants were selected alter a 2-year study of a space-planted mursery. These were cloned and on the basis of yield, lealiness, and frecdom hom leal-spotting diseases, 21 clones were allowed to reproduce by natmal cross-pollination.

North Commercial is a variety of the northern type and not adipted in the southern latitudes. 


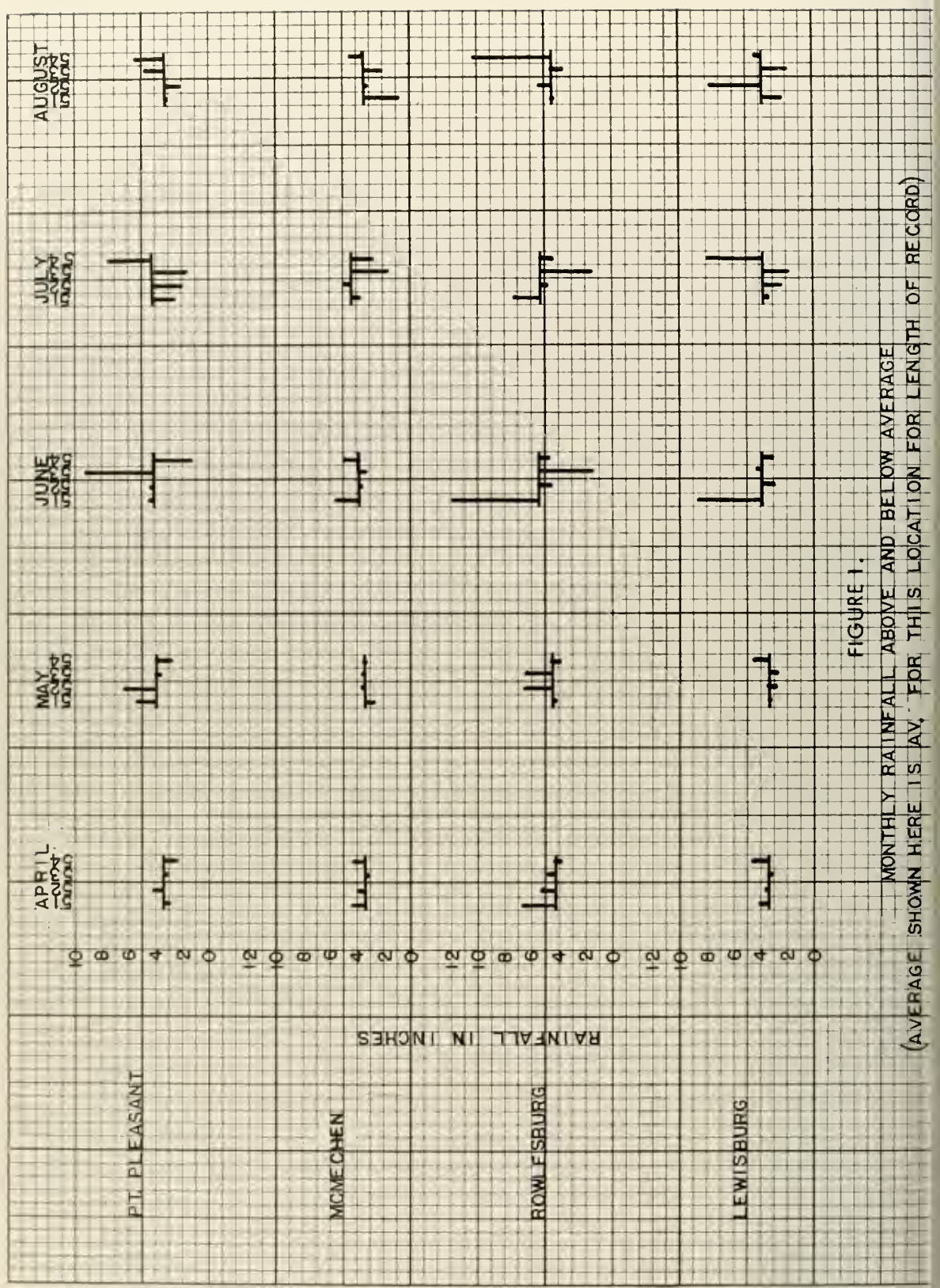


Seed was broadcast and each area was cultipacked after seeding. The spring-seeded plots were nowed in August for weed control. No companion crop was seeded.

The plots, 12 × 30 leet in size, were arranged in random blocks with four replications at Point Pleasant and three replications at all other locations.

The smooth brome grass plots were harvested as hay for three years at all locations except Moundsville where only two years data are available. The lirst cutting was made when grass heads were exposed but before bloom. The second and third cuttings were made when alfalfa was $1 / 2$ to full bioom. Either two or three cuttings were made depending on locations as shown in Tables 1 and 2.

Yield's were detemined by cutting a 30-inch swath lengthwise through the center of the experimental plot. The forage from the cut area was weighed, dried, and yields reported in tons dry matter per acre.

To determine the contribution of smooth brome grass to the total forage yield, botanical estimates were made on all dry matter samples. In this procedure the dry matter samples were taken from the sample bag, spread out on a table, and the percentages of smooth brome grass and legume fractions were estimated. These estimations were then used to calculate the final yields of the smooth brome grass fraction.

\section{Discussion of Results}

Tables 1 and 2 show the total yield of smooth brome grass plus legumes and the yield of smooth brome grass fraction as well as the relative ranking of both spring and summer seedings at all locations. These data show that the southern varieties of smooth brome grass are generally better adapted to West Virginia conditions than the northern or intermediate varieties. Achenbach, Elsberry, Fischer, Lincoln, Oklahoma No. 1, and Southland were the high producing southern varieties.

Yield differences, when significant, were generally between the southern and morthern varieties. Lancaster, a southern variety, frequentIy produced significantly less than the other southern varieties. Manchar was the best of the intermediate varieties and produced well at Point Pleasant and Reedsville. Observations indicate that Manchar recovers well alter harvest and may be used to advantage for pasture. North Commercial, a northern variety, and Martin, an intemediate variety, were consistently low in yield.

No significant differences were founct at Reedsville, a high-altitude location, between varieties for yield of smooth brome grass fraction. One possible explanation for this is that the northern and intermediate varietics are better adapted at higher altitudes than at lower altitudes. 


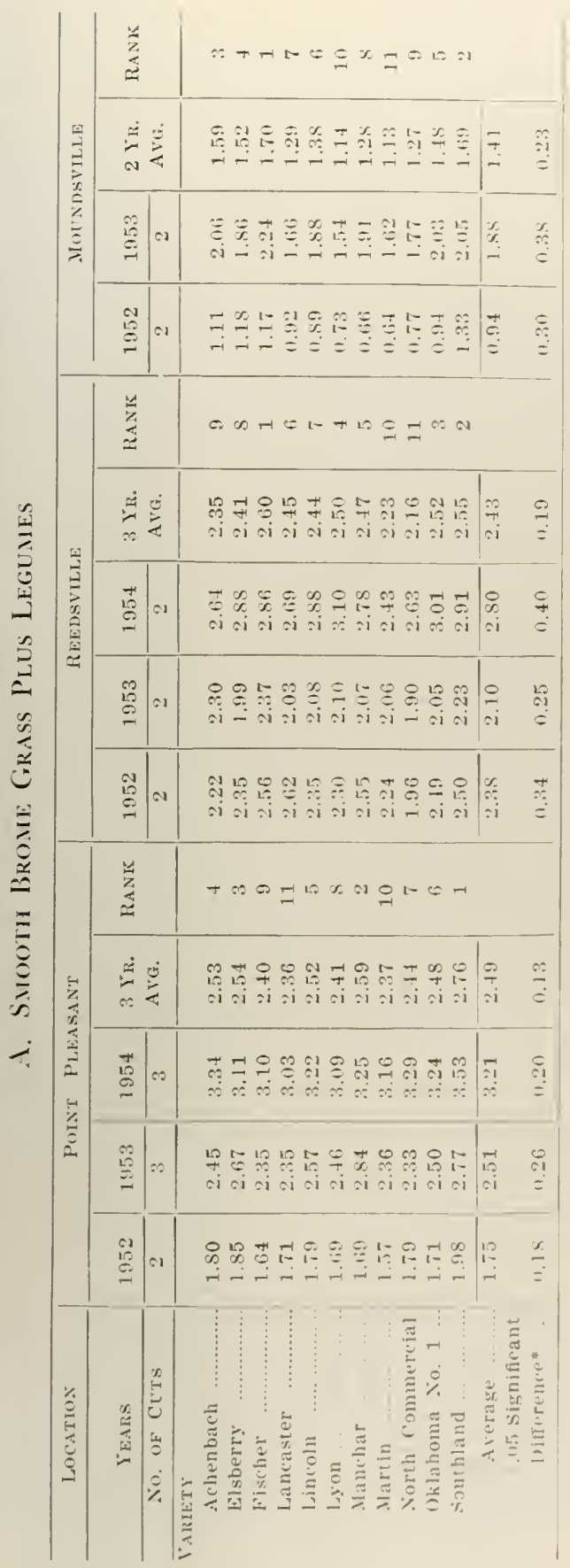

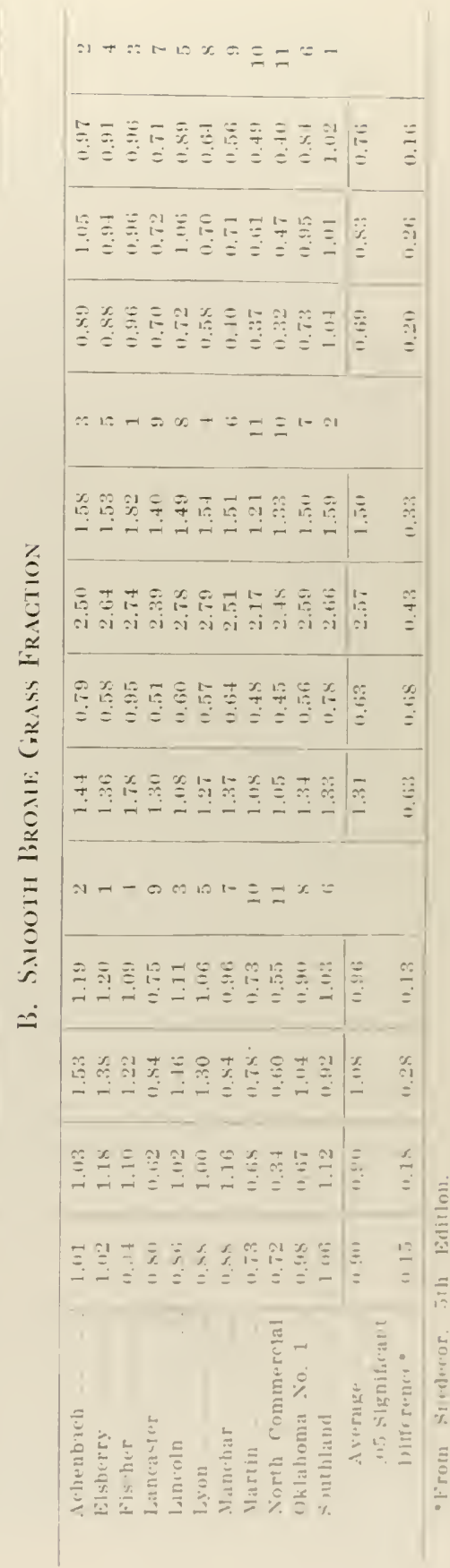




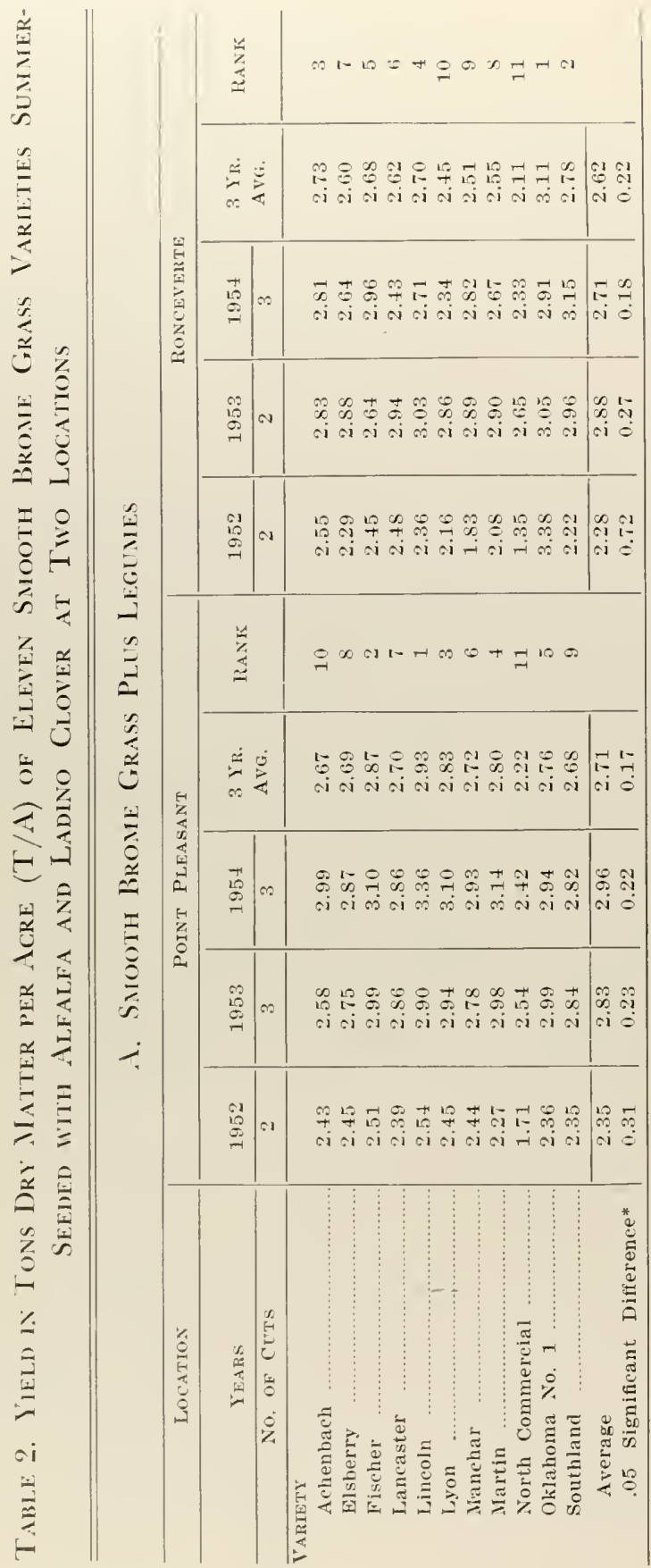

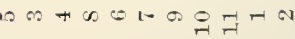

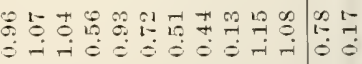

की ना

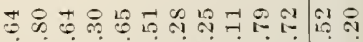
bे $\dot{0} \dot{0} \dot{0} \dot{0} \dot{0} \dot{0} \dot{0} 0$

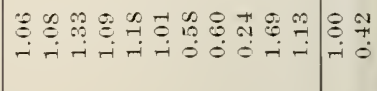

tame tat

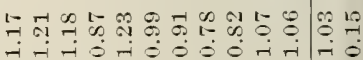
0
0
0
0
0
0
0

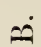

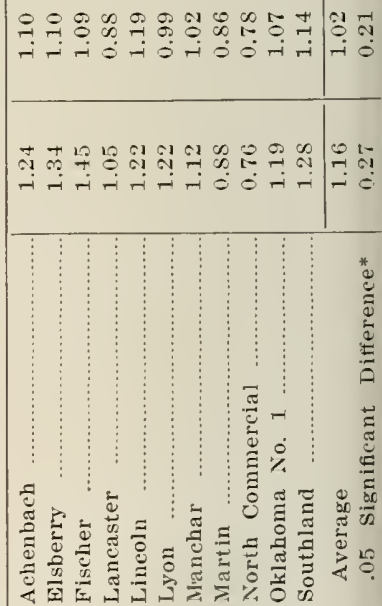


The percentage of smooth brome grass fraction of the total yield of he smooth brome grass-legume mixture for spring and summer seeding, ; shown in Table 3. It is evident that the contribution of the fraction f smooth brome grass varieties is not the same at all locations. Achenach, Elsberry, Lincoln, and Southland in general contributed the most o the total yield. The average percentage of smooth brome grass fracon was lowest in 1953 at Ronceverte, Reedsville, and Moundsville, hereas the contribution of smooth brome grass to total yield at Point leasant became progressively less each year and was the lowest in 1954.

The yield in tons dry matter per acre of smooth brome grass varieties rown with alfalfa and Ladino clover combined for all locations and ercentage of contribution of smooth brome grass fraction to yield of re mixture are given in Table 4. This is shown graphically in Figure? hich shows that Southland with alfalfa and Ladino clover produced ie highest average total yield at five locations in West Virginia. Fischer as the top producer based on estimates of smooth brome grass fraction. orth Commercial produced the lowest average total yield and lowest nooth brome grass fraction yield of any of the varieties studied.

Five of the eight southern varieties produced higher than average tal yields. One intermediate variety, Manchar, was average and anher intermediate variety, Martin, was below average. The contribuon of smooth brome grass fraction to total yield was above average $r$ six of eight southern varieties. The contribution of smooth brome ass fraction of intermediate and northern varieties was below average. I general, alfalfa contributed less by weight to total yields where smootl ome grass yields were high.

Low yields of smooth brome grass in 195.3 were apparently due to w rainfall during the growing season.

\section{Immary and Conclusions}

1. Smooth brome grass made satislactory production for hav in rociation with alfalfa at five locations in West Virginia.

2. Southern varieties produced consistently higher yichls than inmediate or northern varieties.

$\therefore$ Achenbach, Elsberry, Fischer, Lincoln, Oklahomia No. I and uthland were the bigh producing southern varieties.

1. Smooth brome grass and be established sattistatenty when receled her in the spring or summer. 


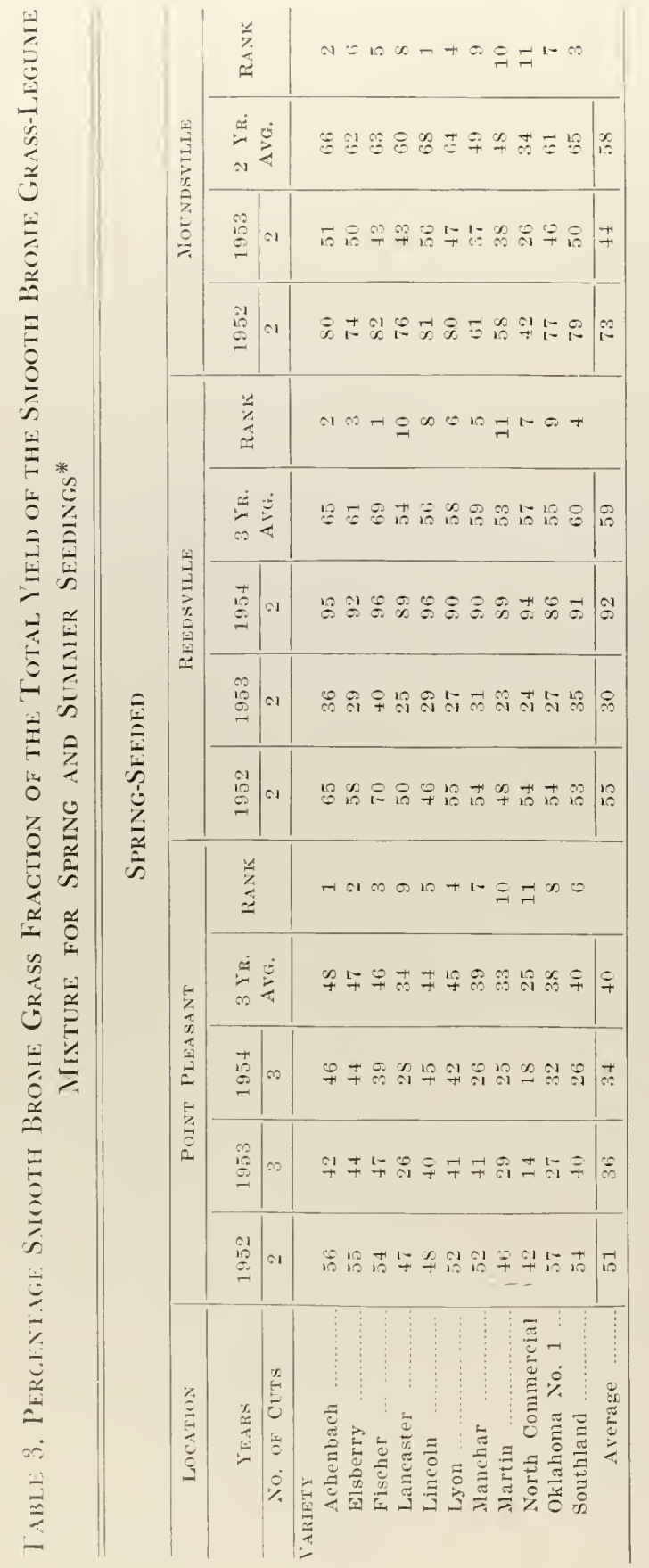

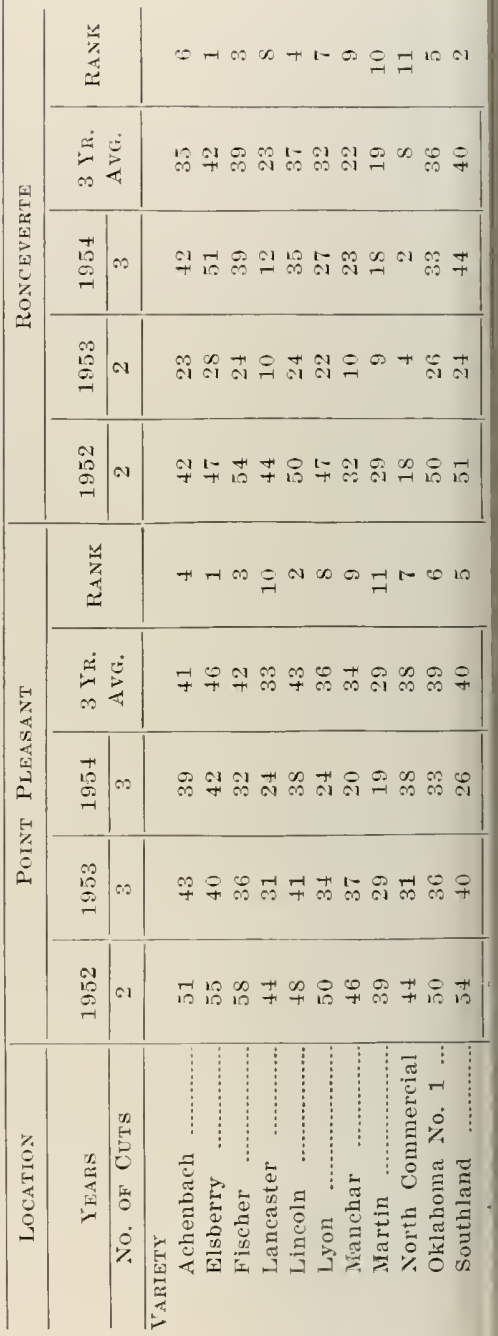




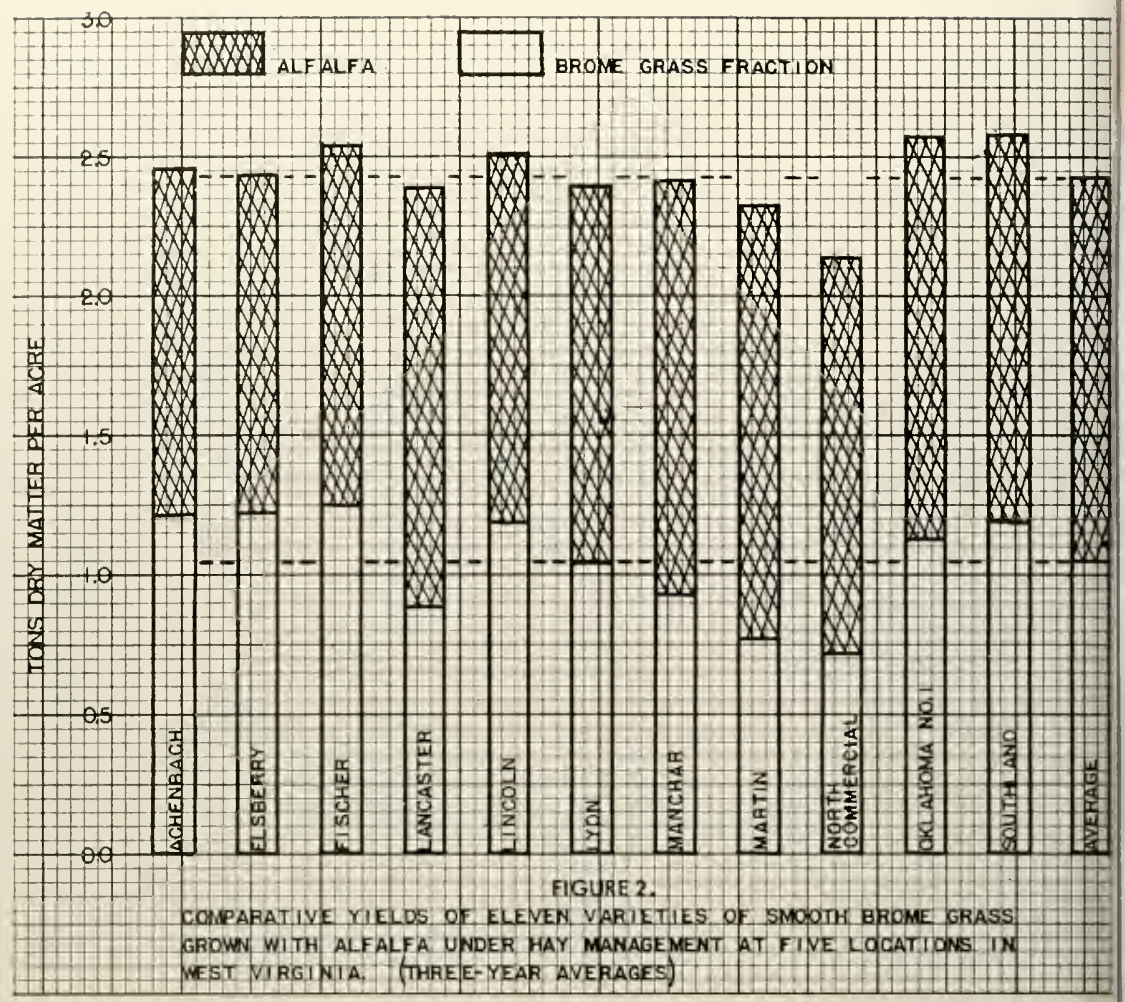

